\title{
カザフスタン共和国のナウルズ（НАУPЫ3）に見る 食の文化的・歴史的特徴
}

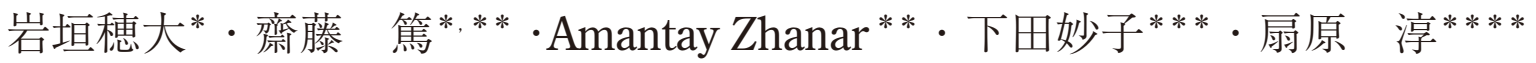

(*早稲田大学大学院人間科学研究科, ${ }^{* *}$ アル・ファラビカザフ国立大学東洋学部,

***東京医療保健大学医療保健学部, ****早稲田大学人間科学学術院)

(平成25年 6 月 24 日受付，平成25年11月13日受理)

\section{The cultural and historical characteristics of ethnic cuisine served at nowruz in the republic of Kazakhstan}

\author{
Takahiro Iwagaki *, Atsushi Saito *,**, Amantay Zhanar**, \\ Taeko Shimoda ${ }^{* * *}$, Atsushi Ogihara**** \\ * Graduate School of Human Sciences, Waseda University, \\ 2-579-15, Mikajima, Tokorozawa-shi, Saitama, 359-1192 \\ ** Faculty of Oriental Studies, Kazakh National University Named after Al-Farabi, \\ 95a Karasai Batyr, Almaty, 050012, Kazakhstan \\ *** Faculty of Healthcare, Tokyo Healthcare University, 3-11-3, Setagaya, Setagaya-ku, Tokyo, 154-8568 \\ **** Faculty of Human Sciences, Waseda University, \\ 2-579-15, Mikajima, Tokorozawa-shi, Saitama, 359-1192

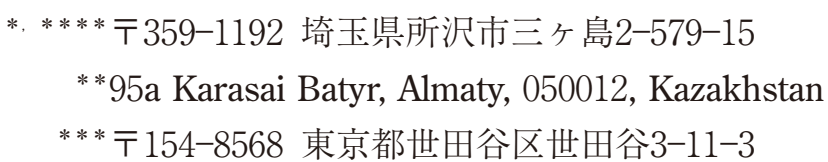

This study investigated the cultural background and historical transformation of the ethnic cuisine served at Nowruz Festival which celebrates the Lunar New Year in the Republic of Kazakhstan. This study aims to clarify (1) The present condition of the ethnic cuisine called Koje that is main dish at the festival, (2) The meaning of ingredients put into the Koje and (3) How the festival and ethnic cuisine have changed through the Soviet era, the independence period and present era.

In previous studies, nutritional assessment and meal survey of Kazakh have been performed since around 1994. In addition, dining etiquette and meals at the time of performing religious rituals have also been researched. However, the study to clarify the cultural and historical background of the ethnic cuisine in a festival like Nowruz has not been done.

The research method was participant observations for the events related to Nowruz and interviews of residents using the semi-structured interview technique.As a result, the following results were clarified. (1) Koje had been freely distributed to every people in the square of all races which live in Kazakhstan that participate in a festival. (2) It was common in all the homes to put in 7 ingredients such as horsemeat and white ingredients in order to wish for the family's prosperity and happiness. (3) There are 3 types of celebrations of Nowruz in the Soviet era depend on the geographical, psychological and political distance from the Soviet government and population density of the Kazakh people.

Based on this study, we were able to show that the values and daily lives of the Kazakh people strongly affect to the ethnic cuisine in Nowruz. 


\section{1.はじめに}

カザフスタン共和国（以下，カザフ）は，1991年12月 に崩壊直後のソビエト連邦（以下，ソ連）から独立した 国家である。面積は $2,724,900 \mathrm{~km}^{2}$ と世界第 9 位の広大 な国土を有し，古くからの牧畜生活に由来した歴史，文 化を持つ国である1)。

現在，同国は豊富な天然資源を背景に，急速な経済発 展をとげている。特に, 2011年のウランの生産量は1.9 万 $\mathrm{t}$ で世界第 1 位である ${ }^{2)}$ 。民族構成はカザフ人 $63.1 \%$, ロシア人 $23.7 \%$, ウズベク人 $2.8 \%$ ，などであり，その他， 100を超える民族が共生している ${ }^{31}$ 。

牧畜が盛んなカザフ人の食生活は馬・羊・ヤギ・牛な どの肉や乳，北部の広大なステップ地域からとれるじゃ

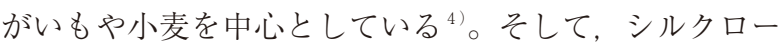
ドの中継都市として栄えたことから，中国やヨーロッパ 地域の食文化の影響も受けている ${ }^{5)}$ 。

カザフ人は親族や友人との関係を非常に大切にする民 族である。そのため, トイ（ТОЙ）と呼ばれる人生の節 目や季節の訪れを祝う行事では，大勢の親族や友人が集 まり，盛大に食卓を囲み扮祝いをする ${ }^{6)}$ 。中でも，毎年 3 月に行われる，季節のトイの一つであるナウルズ (НАУРЫ3) は，国内最大規模の祝祭としてカザフ人に 古くから親しまれている。筆者らがこれまでに行ったナ ウルズの食事に関する調査では，コジェ（KӨЖE）と呼 ばれる日本のおかゆに似た料理が，他の祝宴で出される ものと異なることが明らかになった。コジェは馬・羊な どの肉や米・キビなどの穀物が多く使われており，カザ フの食を象徵する料理であった。

先行研究として，1994年頃よりカザフの食事調査や栄 養評価が行われているほか，宗教儀礼を行う際の食や食 事作法についての研究も行われている。しかし，祝祭の 中での食を取り上げ，文化的・歴史的背景を明らかにす る研究はこれまでにない。

そこで本研究では，カザフのナウルズにおける食とコ ジェに入れる食材の種類や調理法，それらの文化的・歴 史的特徴について明らかにすることを目的とした。

\section{2. 方 法}

\section{（1）調査期間・場所・対象}

調査は2012年 3 月 7 日から23日の日程で行った。調査 地はアルマトゥ州アルマトゥ（旧名アルマ・アタ）市と した。調査方法はナウルズ行事への参与観察と住民への インタビューである。同市は同国南東部に位置するアル マトゥ州に属し，1929年に旧カザフ自治・ソビエト社会 主義共和国の首都として定められ，1991年12月にカザフ スタン共和国成立後も1998年にアスタナ市に遷都される まで同国の首都として機能した。市面積は $324.5 \mathrm{~km}^{2}$ と, 現首都のアスタナ $\left(722 \mathrm{~km}^{2}\right)$ に比べると小さいが, 人 口は2012年 1 月 1 日時点で約 145 万人と同国最大規模を
誇っている7)。この内 $51 \%$ \%カザフ人，33\%をロシア人 が占めている (2010年度)。現在は政令指定地区と位置 付けられ，アルファラビー・カザフ国立大学をはじめと した各種高等教育機関や研究機関が存在するほか, 大規 模なバザールを複数擁するなど，現在も同国における教 育・経済の中心的役割を果たしている。

現在，カザフスタン国内では，国家語としてのカザフ 語, 国際交流語としてのロシア語, グローバル経済への 順調な統合のための言語としての英語の 3 つの言語を重 視した政策が掲げられている ${ }^{8)}$ 。一方で，カザフ人人口 の増加とロシア人人口の減少やロシア語学校の生徒数の 減少によって, カザフ語話者が増加し， ロシア語話者が 減少することが予想されている ${ }^{9)}$ 。カザフスタン南部で はカザフ語学校が圧倒的に多いが，アルマトゥ市内では, 将来のことを考えた保護者が子どもをロシア語学校に通 わせるケースも多い。また，アルマトゥ市内のカザフ人 は，カザフ語とロシア語を自由に話す人が多いが，ロシ ア人をはじめとしたカザフ人以外の民族では，ロシア語 と自国語のみで，カザフ語を話せない人も多数いる。

まず，参与観察は，アルマトゥ市内の公共の場で行わ れている行事と民家で行われている行事について行った。 次に，インタビュー調査はアルマトゥ市内および郊外に 住むカザフ人を対象に行った。年齢, 性別, 出身地に考 慮し，機縁法により20名に調査を依頼した。そのうち， 協力が得られた 8 名（男性 2 名，女性 6 名，年齢30〜84 歳）を対象にした。

日本語，カザフ語，ロシア語を介したインタビュー調 査のため, 言葉の意味や解釈の複雑さに配慮し, 複数の 言語を理解する 2 名に通訳を依頼した。倫理的配慮とし て, インタビューへの回答は強制ではなく, 不都合が生 じた場合はいつでも調査を中断できる旨を事前に伝えた。

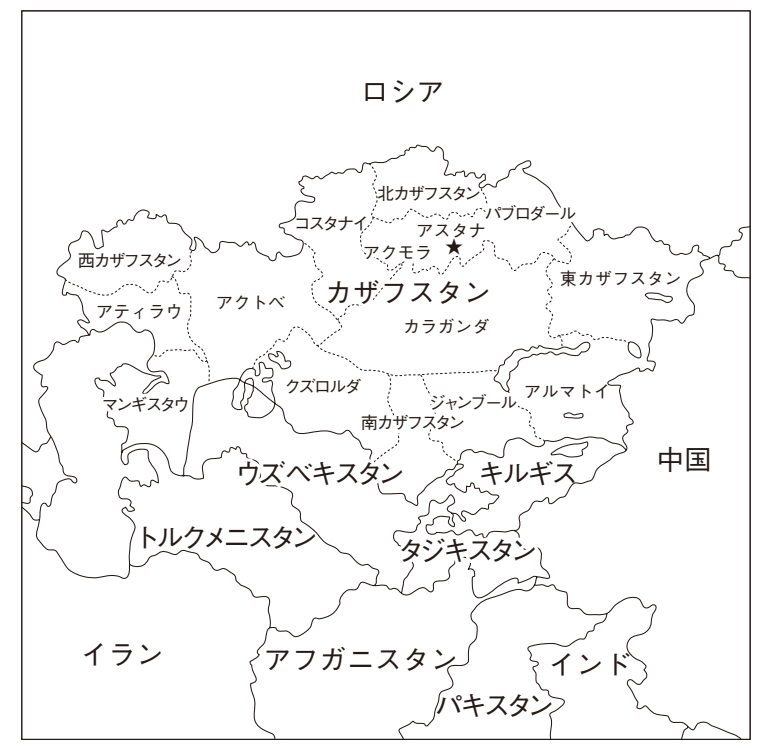

図 1 調査地の地図 


\section{3. 結果・考察}

（1）市内のナウルズのイベントと料理

カザフ政府は1992年に毎年 3 月22日を正式な国家のナ

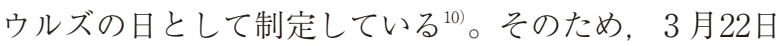
を中心に前後 2 日間が会社や学校の休日となる。2012年 は3 月20日から25日がナウルズに関連する祝日であった。 休み当日になると, シムケント (ШЫМКЕНТ) やセメ イ (CEMEЙ) などの地方都市に向かうバスが多く運行 され，帰省客で幹線道路は混雑していた。また，同市で 最大規模のコク・バザール (Көк базар), バラホルカ・ バザール（БАРАХОЛКА БАЗАРЫ）には，ナウルズのハ レ食作りのための材料（肉や野菜，乳製品や果物など） が店頭に並べられた11)。

公共の場でのナウルズのイベントは行政地区ごとに行 われる。各区にナウルズの担当者が決められており，担 当者を中心に予算や規模，催し等が決定される。今回は アルマトゥ市を構成する 7 つの行政地区のうち, 市内中 心部に位置するボスタンドゥック区 (Бостандық) のイ ベントに参加した。ボスタンドゥック区は面積 $2,777 \mathrm{~km}^{2}$ ，人口 285,394 人の区である。アルマトゥ市 で第二の人口を誇り，その民族構成はカザフ人が $58 \%$, ロシア人が $32 \%$ ，その他の民族10\%である ${ }^{12)}$ 。

広場ではコジェ（次項（2），（3）で詳しく説明）と 呼ばれる日本のおかゆに似た料理が参加者全員に無料で 振る舞われていた。カザフ人以外の民族は家でコジェを 作る習慣がなく，広場でコジェを食べることで春の訪れ を実感する。無料で配られることで, 誰もが気軽に祭り に参加でき，民族を問わずすべての住民が祭りを祝うこ とができるよう工夫されていた。さらに，広いスペース では野外ステージが組まれ, 伝統衣装を着た奏者がドン ブラ (ДОМБЫРА) やコブスを演奏したり，ダンスを踊っ たりしていた ${ }^{13)}$ 。カザフ人だけでなく, 異なる民族の人々 も，それぞれの音楽，ダンスで会場を盛り上げていた。 広場に設営されたブースには区内の主要なレストラン が出店しており，羊肉の大きな塊を串刺しにしたシャシ

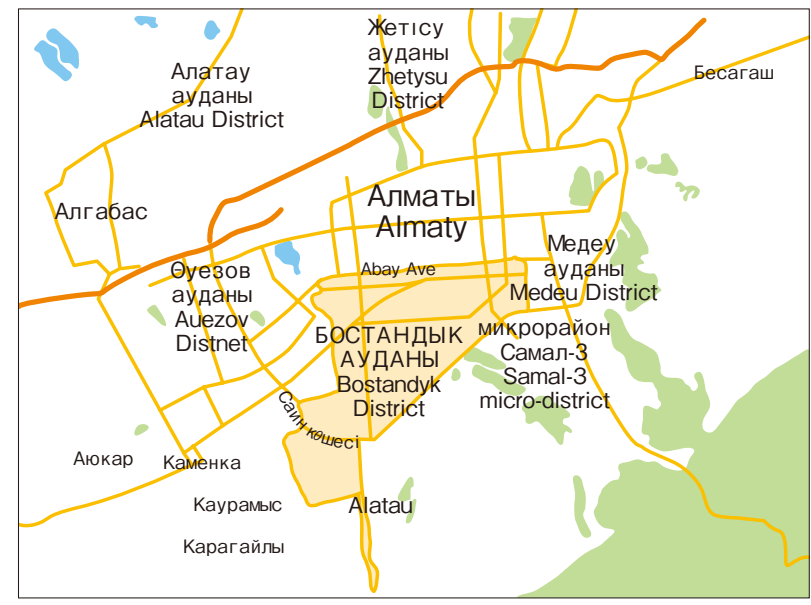

図 2 ボスタンドゥック区（で示された場所）

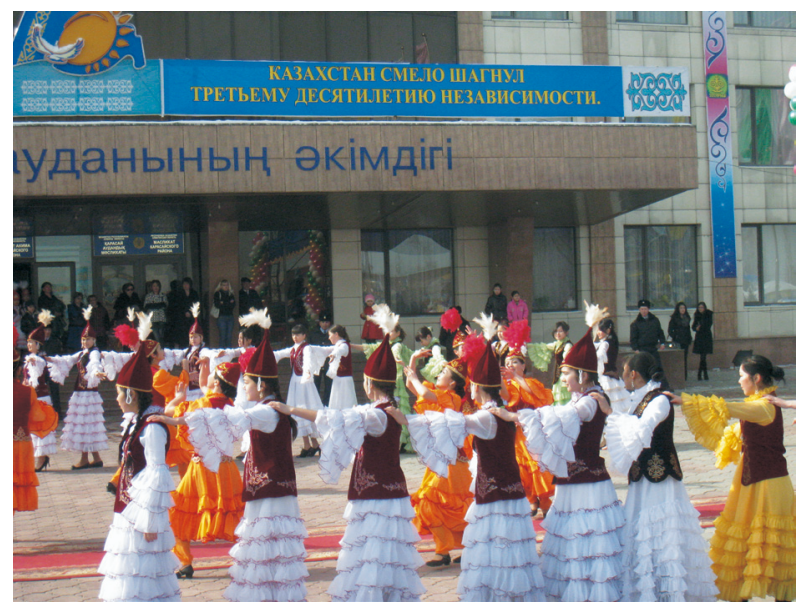

写真 1 広場で踊られる伝統ダンス

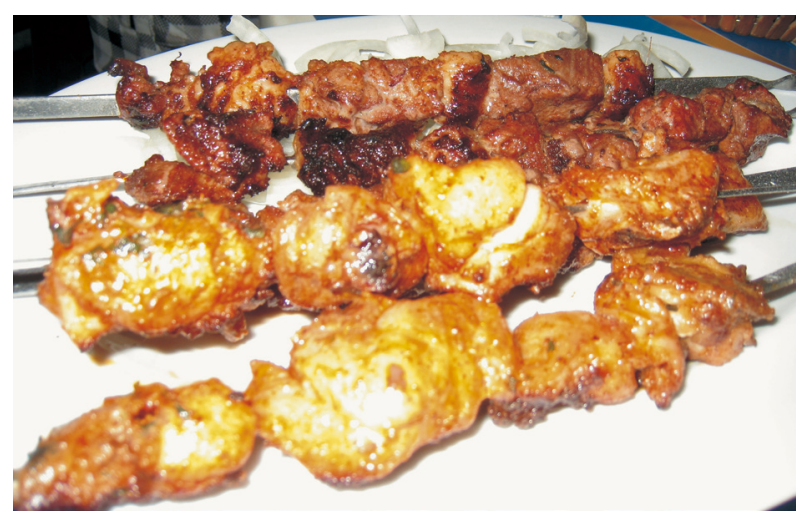

写真 2 羊の肉に味付けし焼いた料理シャシリク

リク（ШАШЛЫК：ケバブ）を専用のコンロで豪快に焼 いていた。肉の焼ける香ばしい香りと独特のけむりが広 場に集まる人々の食欲をそそっていた。「カザフ人は世 界で 2 番目によく肉を食べる。世界で 1 番は狼である」 という言葉があるほど, カザフ人の生活と肉は密接な関 係にある。主に食されるのは馬肉, 羊肉である。ナウル ズではさまざまな料理が振る舞われるが，その中のメイ ンディッシュも, カズ (ҚАЗЫ：馬の肉と脂の腸詰）や シャシリクなどの肉料理である。カザフは，豊富な飼料 資源や豊かな自然環境に恵まれ，古くから畜産業が盛ん に行われてきた。ソ連からの独立直後は, 深刻な社会混 乱の影響から，食肉の生産が大幅に落ち込んだ時期も あった ${ }^{14)}$ 。しかし現在では供給も安定し，2010年の馬肉 生産量は114,000tで, メキシコの140,000t, 中国の 126, 000 tに次いで，世界第 3 位である ${ }^{15)} 。$

加えて, 肉料理と同様に, 必ず祝祭のテーブルに並ぶ （日常の食卓でも必ず食される）のがバゥルサク (БАУЫРСАК) である。バゥルサクは小麦粉に卵, バター, ミルクまたはソルパ（肉をゆでたスープ）を混ぜて生地 を作り，油で香ばしく揚げたものである。小麦粉を使っ た料理は食卓のメインとして食されるほか, 肉料理を引 き立てる役割も果たす。

カザフは小麦など穀物の輸出国としても知られている。 カザフ人は元来, 牧畜民族であるため, 農耕は一部でし 


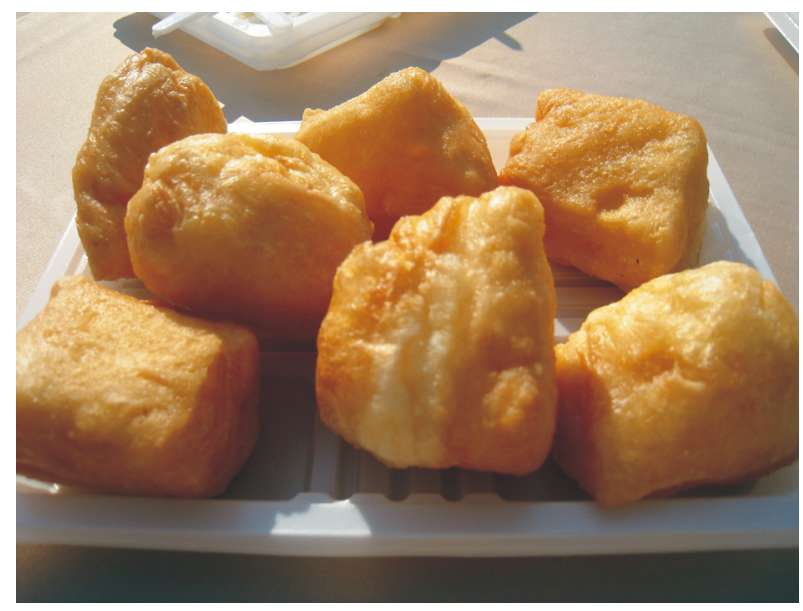

写真 3 バゥルサク

か行われていなかった。しかし，1930年代からソ連政府 が行った定住化政策とともに，特に北部地域が次々に開 発され, ソフホーズ $(\mathrm{COBXO3)・コルホーズ} \mathrm{(КОЛХО3)}$ において穀物大量生産が行われた。食肉同様, 独立直後 は社会の混乱とともに生産高は大幅に減少した ${ }^{16)}$ 。現在 では，穀物類の生産量は独立前の半分程度であるが，な お中央アジア地域のみならずョーロッパ地域, 中東地域 へ供給され続けている ${ }^{17)}$

広場には, 遊牧民時代のカザフの伝統的家屋であるキ イズ・ウイ (киіз үй) が多数建てられていた。この地区 のナウルズを管轄する市担当者によると,「キイズ・ウ イは, 各職場や学校ごとに所有されている。決められた 場所, 期間を守り, 許可を貪えば誰でも建てることがで きる。キイズ・ウイの内部のテーブルには, 馬乳酒であ るクムズ (ҚЫМЫ3) や肉, にんじん, 玉ねぎと米を炒 めたポロフ (ПАЛАУ), 太い曙の上にゆでた野菜と肉を のせた料理ビシュパルマック (БЕШПАРМАҚ) 等を並 ベる。そして, ダスタルハン (ДАСТАРXАН : 宴会) を 行う」ということであった。カザフ人はダスタルハンに おいて, 料理を盛大に囲み, 健康を喜び, 苦労をねぎら うことで互いの関係を深めていた。

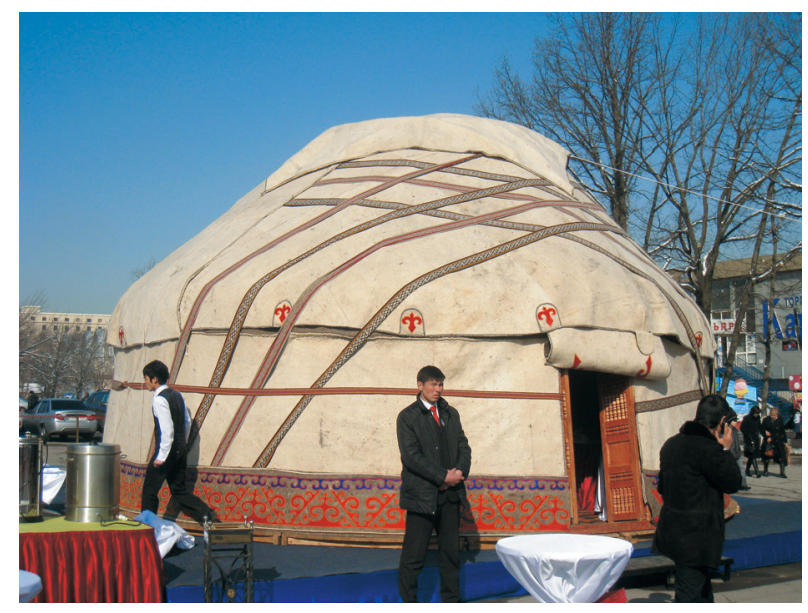

写真 4 広場に建てられた伝統住居キイズ・ウイ

\section{（2）コジェの文化的背景}

カザフの各家庭では 3 月上旬になるとナウルズの伝統 料理, コジェが作られ, 家族・親戚・近隣の方との行き 来が始まる。また，4月になり暖かくなると, 友人や職 場の同僚と近くの山に建てられているキイズ · ウイに出 かけ，祝うこともある。

同国には家族・親戚縁者のみならず遠来の客を非常に 大切にするという習慣がある。来客を手厚くもてなし, 困った人を助け, 必要なときに他人を自分の家に泊めな ければならない。ナウルズ期間中，30軒以上の家を訪問 し，頻繁にお互いの様子を確認し合っている人もいる。 周囲の人を大切にすること, 客人を手厚くもてなすこと は不安定な牧畜生活を生き抜くためにカザフ人が大切に してきた慣習であった。

コジェに入れる材料は各家庭, また地域によって少々 異なる。作る人の味付けの好みや，その地域で採れる特 産物などで特徵が出る。しかし,「7 種の具を入れること」, 「白色の食品を最後に入れること」の 2 点はどの家庭の コジェにも共通していた。

ナウルズはイラン暦の正月を祝う祭りであり，2009年 にはUNESCOによって世界無形文化遺産に登録され た ${ }^{18)}$ 。ゾロアスター教との関連が深く, 初めて行われた ナウルズの日は, 善神「アフラマズダ」の生まれた日と されている ${ }^{19)}$ 。たた, ナウルズはイランで発祥し，その 後テュルク諸国に広まったため, イランの影響も受けて いる。カザフのナウルズにおいて「7」が大切にされる 理由も，イランの歴史に由来するとされている ${ }^{20)}$ 。

コジェは完成の直前に白い食材を入れ，全体の色を整 える。白色は, カザフ人にとって大切な家畜の乳の色で あり。繁栄の象徴とされている。一年の始まりを祝うナ ウルズにおいて, 家畜が生まれたときに最初に口にする 乳の色にコジェを整えることで, 一年間の繁栄と幸せを 願う。同時に人間の乳も白色であり, 白いものをたくさ ん食べることで大きく立派に成長し，子孫を繋いでいけ るようにという願いも达められている。コジェを食す前 には必ず「アクモルボウスン」(Ақ мол болсын : 白がた

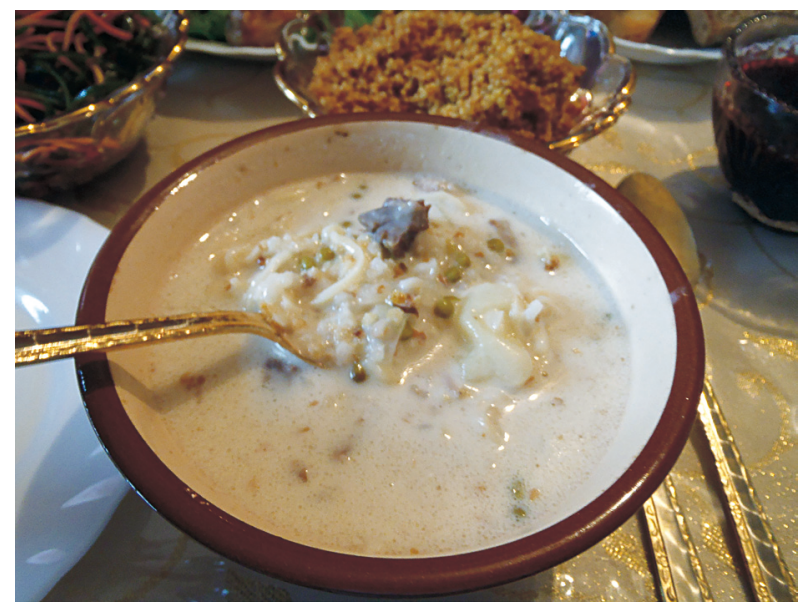

写真 5 ナウルズコジェ（HAYPb|3 KӨЖE） 
くさんありますように）というカザフの祝いの言葉が述 ベられる。

こうした傾向に関して，アジア地域における色彩嗜好 調査によると，アジアの広い地域にわたって白嗜好が見 られることが指摘されている 別や年齢といった個体的影響のみならず，地理的・文化 的要因によっても影響されることを示している。同国に おいて「白」は家畜のミルクの色であり，民族の繁栄や 幸福の象徵であるという文化的背景が，ナウルズで白を 好みコジェを白色に整える要因になったと考えられる。

\section{（3）家庭でのコジェ作り}

筆者らはナウルズ期間中，一般家庭へ訪問し，コジェ 作りの観察を行った。訪問した家庭では, (1)クルシュ (КYPIШ：米)，(2)キスぺ (KECПE：小麦粉，卵，ソル パをまぜた麺), (3)ジルキニン・エティ（ЖЫЛҚЫНЫҢ ETI：馬肉), (4)マ (MAШ : 緑色の小さな豆), (5)夕 リ（ТАРЫ：炒ったきび), (6)グレーチカ（ГРЕЧКА：蓠 麦の実), (7)カトゥク (ҚАТЫҚ: 羊・ヤギ・牛のミルク を一旦煮沸させ，スメターナ「CMETAHA」を入れ 2 ， 3 時間醗酵させたもの)，8カルトプ（КАРТОП：じゃ がいも), (9ピヤズ (ПИЯ3：玉ねぎ)，(10)トゥズ（Т¥3

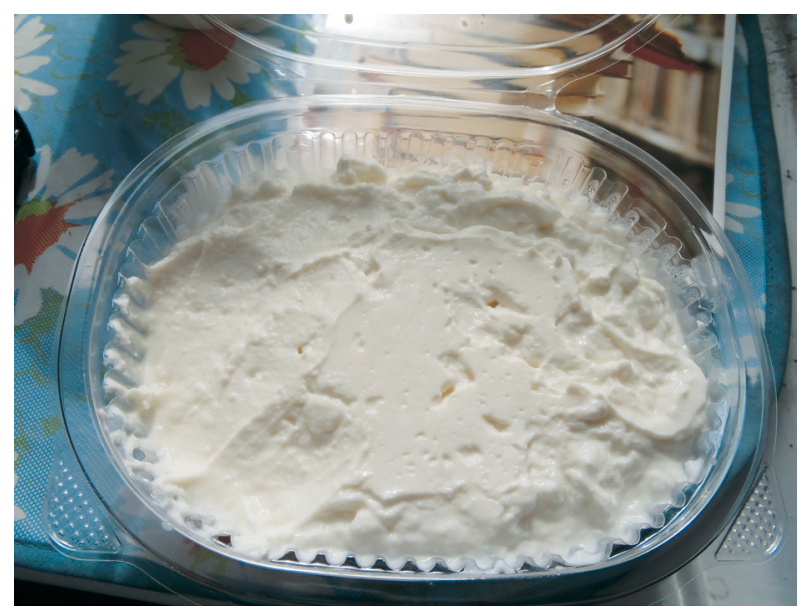

写真 6 コジェを白色にするカトゥク（KATbK）

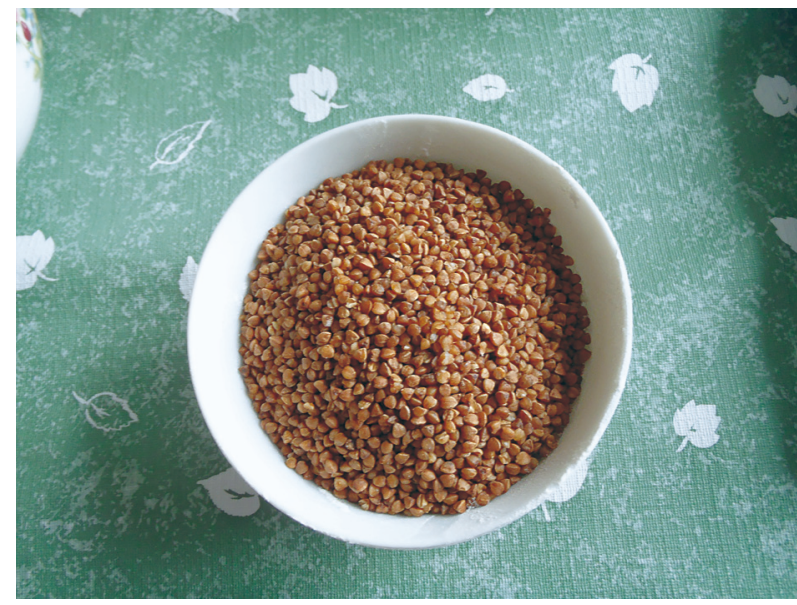

写真 7 きび (TAPЫ)
塩)，(11)カイマッカ（ҚАЙМАҚ：甘くないヨーグルト状 のもの）を食材として使用していた。食材は厳密に 7 種 類しかコジェに入れてはならないのではなく，7 種類以 上であればよいが，奇数の種類数にこだわる傾向があっ た。

作り方は，まず大きな鍋で水を沸騰させ，炒めたピヤ ズ，細かく切ったカルトプ，トゥズを入れる。カルトプ が柔らかくなったところでクルシュ，タリ，グレーチカ, マシを順番に入れ，かき混ぜながらよく煮込む。ひと煮 立ちしたところであらかじめ茹でておいたキスペとジル キニン・エティを加える。最後にカトゥク，カイマッカ を混ぜたものを加え，全体を白で整えて完成である。見 た目は日本のおかゆによく似ている。穀物の香ばしさと 肉から出るうま味がよく効き，またカトゥク，カイマッ カの酸味が全体のバランスを引き立てているためとても 食べやすい。

ダスタルハンはアガイ（Ағай：年長の者）の「アク モルボウスン (Ақ мол болсын : 白がたくさんあります ように)」,「アス・ボルスン (АС БОЛСЫН : 食べ物が たくさんありますように)」というバ夕（Бата：お祈り） の言葉から始まる。食事中は日本の上座に相当する場所 に主賓が座り，家の主人が料理を取り分ける。

ナウルズのコジェに入れられる肉は，前年の秋に別か れた，冬季の備蓄食料（ソーグン：Соғым）を使用する。 カザフでは冬が近づくと，厳しい寒さをしのぐための食 料として，一頭の家畜を別き，家族・親戚で分ける。過 去には食料を調達することが困難で，冬を越せずに多く のカザフ人が凍死した時代もあった。そのため, ナウル ズにおいては，無事に春を迎えられたことを喜び，肉を たくさん入れるコジェほど縁起がいいものとされている。

（4) ソ連時代のナウルズとコジェに関するインタビュー インタビューではソ連時代における(1)十ウルズ行事の 有無，(2)友人・親戚・知人の往来の有無，(3)コジェ作り の有無ついて質問した。ソ連時代に限定する理由は，同

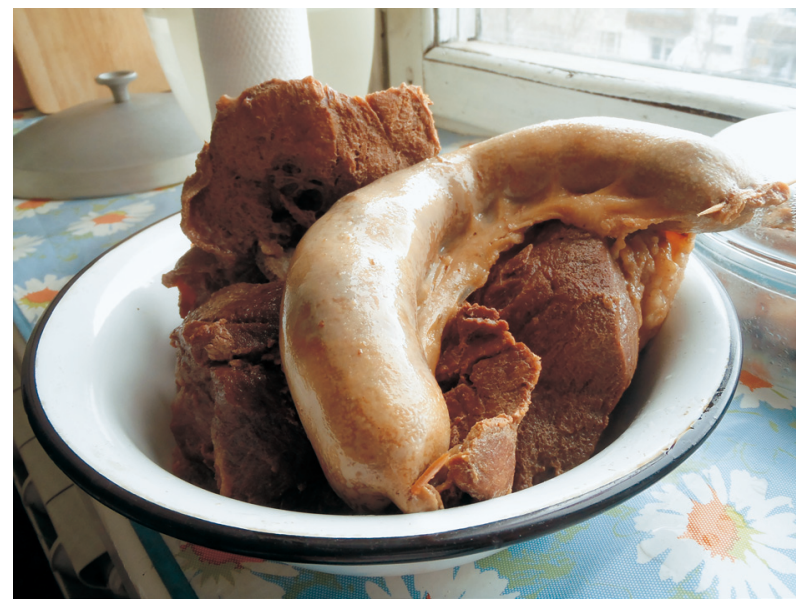

写真 8 コジェに用いた肉（馬肉の腸詰） 
時代においてカザフのあらゆる文化活動が禁止されてお り，どのような地域でナウルズを祝う伝統が消滅し，ま たどのような地域で伝統が継承され続けてきたのかを明 らかにするためである。その結果, ソ連時代のナウルズ の祝い方は大きく 3 種類に分けられた。表 1 より, イン タビュー対象者 $\mathrm{A}, \mathrm{B}, \mathrm{C}, \mathrm{D}, \mathrm{E}$ は公にナウルズを祝い コジェ作りを行っていたことがわかる。また，対象者 $\mathrm{F}$ は地域でも家庭でも全く祝わず，コジェも作らなかった ことがわかる。最後に, 対象者 $\mathrm{G}, \mathrm{H}$ は家の中だけでコ ジェを作り祝っていたことがわかる。

図 3 はインタビューを行った 8 名の出身地を地図上に 示したものである。まず, 対象者 $\mathrm{A}, \mathrm{B}, \mathrm{C}, \mathrm{E}$ は南東 部の農村出身であった。

これらの地域では, カザフ人の人口密度が高く, ロシ ア人はほとんど住んでいなかったため，比較的自由にナ ウルズを祝っていた。そのため，馬で競い合う「バイゲ (БӘЙГЕ)」や大きなブランコのような遊びである「ア ルトバハン (АЛДЫБАҚАН)」も行われていた。キイズ . ウイを建てたり，家庭へ人を招待したりすることも一般 的に行われていた。あるインタビュー対象者によると「世 界大戦後, 独立直後など食料が不足した時期もあった。 しかし，農村部において，コジェ作りの伝統が途絶える ことはなかった。肉がある人は肉を, 塩がある人は塩を, 穀物がある人は穀物を出し合って皆で一つのコジェを作 り, 裕福な人も, 貧しい人も同じコジェを食べて助け合っ て生きてきた。お互いのつながりがいつまでも続くよう にという願いを込め, 各家庭で作ったコジェを混ぜて食

表 1 ソ連時代のナウルズの実施状況

\begin{tabular}{l|cccccccc}
\hline & A & B & C & D & E & F & G & H \\
\hline Q 1 & $\bigcirc$ & $\bigcirc$ & $\bigcirc$ & $\bigcirc$ & $\bigcirc$ & $\times$ & $\times$ & $\times$ \\
Q 2 & $\bigcirc$ & $\bigcirc$ & $\bigcirc$ & $\bigcirc$ & $\bigcirc$ & $\times$ & $\bigcirc$ & $\bigcirc$ \\
Q 3 & $\bigcirc$ & $\bigcirc$ & $\bigcirc$ & $\bigcirc$ & $\bigcirc$ & $\times$ & $\times$ & $\times$ \\
Q 4 & $\bigcirc$ & $\bigcirc$ & $\bigcirc$ & $\bigcirc$ & $\bigcirc$ & $\times$ & $\bigcirc$ & $\bigcirc$ \\
\hline
\end{tabular}

Q1、あなたの居住地域でナウルズを祝いましたか。

Q2 2.あなたの家庭でナウルズを祝いましたか。

Q 3 . 親戚, 友人, 近所の方の往来がありましたか。

Q4 ああなたの家庭でコジェを作りましたか。

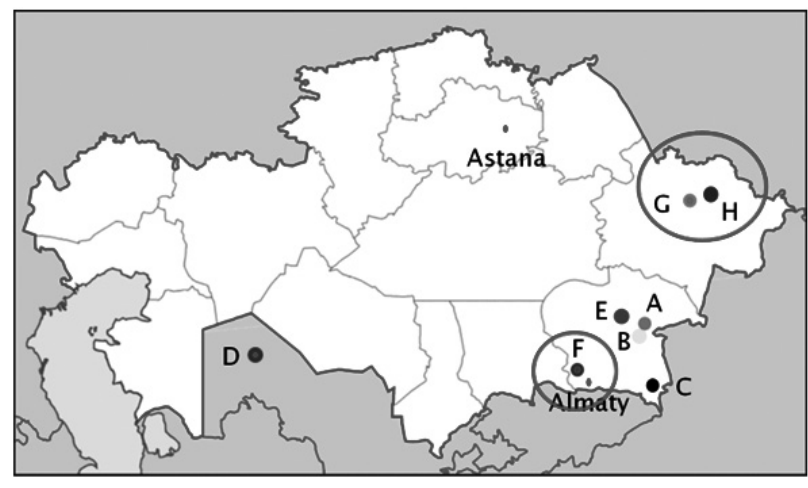

図 3 対象者の出身地分布
ベることもあった」という。ソ連時代においても, カザ フ人の人口密度が高い農村部ではナウルズが盛んに行わ れていた。そして，貧しい時代にあってもコジェを作る ために人々が協力し伝統を繋いでいったことが明らかと なった。

次に，家の中だけでコジェを作りナウルズを祝ってい た対象者 G, H は, 東カザフスタンのセメイ市に近い農 村部出身であった。家族や同居する親戚で祝うが，人の 行き来や屋外での行事は行われなかったという。

最後に，ナウルズを全く祝わず，コジェも作らなかっ た対象者 $\mathrm{F}$ は, アルマトゥ市の中心部出身であった。 ソ連統治下のアルマトゥ市ではソ連の政治的影響力が強 く，カザフ民族文化の弾圧が行われていた222。そして， 1926年からソ連政府によって祝うことを禁止された。そ の後, 初めてナウルズが祝われたのは1987年で, カラガ ルという地域であっだ23)。そのため, ソ連時代はこれら の地域において屋外での行事を行うことは困難であった。 また，教育機関やメディアを通し，ロシア語の強制やソ 連の政治思想の植え付けが行われたため, 家庭内でもカ ザフ民族の伝統的行事を行うことに対しての心理的恐怖 があったと推測できる。結果, ナウルズを祝い, コジェ をつくる行事は $\mathrm{G}, \mathrm{H}$ のような北部で比較的ロシア人が 多い地域では控えめに行われるようになり，Fのような 政治的影響力を受けやすい都心部では全く行われず，後 世にも受け継がれなくなったと推測される。

独立直後, 農村部からアルマトゥに移り住んだインタ ビュー対象者によると，「ナウルズを祝わず，コジェを 食べたことがない, 作り方を知らない人も多くいた。私 たちは夫婦で広場に出て無料でコジェを配ったり，作り 方を教えたりした。アルマトゥ市のコジェにさまざまな 味があるのは, 独立後, 地方から移り住んだ人が, その 地方の味を伝えたからだ」という。現在のような形でナ ウルズが復興し盛大に祝われるようになったのは, こう した伝統文化を守ろうとする人々の努力の証であった。

\section{4.まとめ}

今回の調査によってカザフのナウルズおよびコジェに 見る文化的特徵と歴史的変容について以下のことが明ら かになった。

(1) 独立後, ナウルズはカザフ国内最大級の祝祭であり， 民族の伝統的なイベントとして現在に受け継がれてい る。誰でも祭りに参加することができるよう, 広場で は無料でコジェが配られていたり，さまざまな民族の 音楽やダンスが披露されていたりした。その他, 中央 アジアの伝統料理であるシャシリクやバウルサックを 売る店も見られ, 食や伝統芸能を通してカザフ人の世 代間交流や，異なる民族同士の交流が図られていた。

(2) ナウルズが近づくと各家庭でコジェ作りが行われ, 家族・親戚・友人の往来が始まる。コジェに入れる具 材は地域の特産によって少々異なるが，7つ（以上） 
の食材を入れることと, 白色の食材を入れ全体の色を 整えることはすべての家庭で共通していた。コジェに 使わ机る食材はカザフの食卓には欠かせない馬肉や， 穀物類が中心でカザフの日常生活をよく表すもので あった。コジェを白色の食材で整える理由は, 白が家 畜の乳の色であり，新年を迎えるにあたって一家の繁 栄や幸福を願うからであった。

(3) インタビュー対象者の出身地域によってナウルズを 公に祝いコジェ作りも行っていた家庭，家の中だけで コジェを作り祝っていた家庭，全く祝わず，コジェも 作らなかった家庭の 3 つに分けられた。ソ連との地理 的・心理的距離や政治的影響力，カザフ人の人口密度 が影響している可能性が指摘された。独立後，伝統を 復興させるために都市部でナウルズを教える、コジェ を無料で配るなどの活動も行われ，現在のナウルズの 基盤となった。

調査の中で，都心部と農村部でのナウルズの祝い方や コジェに加えられる材料が異なることがたびたび指摘さ れた。そのため，今後農村部を含めたカザフ国内全体の 調查が必要である。また, より詳細で信頼性のある調查 にしていくために調査員を増やし，インタビューを継続 することが必要である。カザフ社会の時代の流机に呼応 する文化の変容を見守りつつ，調查で得られたデー夕を もとに，カザフの伝統的な祝祭と食文化についてさらに 媣く体系的に明らかにしていきたい。

\section{文献}

1) Statistical Yearbook, Agency on Statistics of the Republic of Kazakhstan, Astana, p.7 (2012)

2 ） データブック・オブ・ザ・ワールド（25），二宮書店，東 京, p.184 (2013)

3 ) CIA: THE WORLD FACTBOOK 2013, Skyhorse Publishing, New York, p.383 (2012)

4）下田妙子：食と大地とシルクロード, 食生活. 92（1）,
94-97 (1998)

5 ）先崎将弘：おいしい中央アジア, 東洋書店, 東京, pp.25一 30 (2012)

6 ）宇山智彦：中央アジアを知るための60章（第 2 版），明石 書店, 東京, pp.191-200（2010）

7 ） 前掲書 1), p. 7 (2012)

8 ) Стратегия 《Казахстан-2030》, (Послание Президента Республики Казахстан Н.А (2007)

9）淺村卓生：カザフスタンにおける自国語振興政策及び文 字改革の理念的側面，外務省調査月報， 1 (2011)

10) Әлімқұлов Б : Әбдіраманов Е, Күйеу келтір, қыз ұзат, тойынды қыл, Алматы, pp.77-84 (1994)

11）下田妙子：クジルオルダ市を中心としたカザフのハレ食 と日常食の食事事情, 日本カザフ研究会調査報告書（10）, pp.15-28（2002）

12) Almaty 市統計局 : Численность населения города Алматы по отдельным этносам на начало 2013 года

13）角崎利夫：カザフ草原と資源と豊かな歴史の国，早稲田 出版, 東京, pp.84-86（2007）

14）石田定顕，北川政幸，宮崎昭：カザフ共和国の家畜生産 の現状, 日本カザフ研究会調査報告書 ( 5 ), pp.99-114(1997)

15）国際連合食糧農業機関：FAO 統計データベース, http:// faostat.fao.org/（2012.11. 12閲覧）

16）野村政修：市場経済移行期のカザフ経済，日本カザフ研 究会調査報告書 $(9)$, pp.25-50（2001）

17）農林水产省：海外農業情報調査分析（ロシア・東欧・中 南米）報告書, pp.47-74（2010）

18）吉田陽久, 吉田真美：世界無形文化遺産データ・ブック シンクタンクせとうち総合研究機構, 広島, p.41 (2009)

19) Жұбатова Б. Н : Қазақ тіліндегі араб, парсылық кірме фразиологизмдер, pp.192-193 (2012)

20) Қазбеков М : Наурыз: жаңғырған салт-дәстүрлер, рp. 5-12 (2012)

21）斉藤美穂：色彩喏好の国際比較, 武蔵野美術大学研究紀要, 21, 81-88 (1991)

22）藤本透子：カザフの子育て一草原と都市のイスラーム文 化復興を生きる一，風響社，東京，pp.18-22，(2010）

23）前掲書16), pp. 5-12（2012） 